\title{
QUALITY IMPROVEMENT OF GLUTEN-FREE BREAD BASED ON SOYBEAN AND ENRICHED WITH SUGAR BEET MOLASSES
}

\author{
Olivera D. Šimurina* ${ }^{* 1}$, Aleksandar Z. Radunović ${ }^{1}$, Bojana V. Filipčev ${ }^{1}$, Rada C. Jevtić Mučibabić ${ }^{1}$, \\ Ljubiša Ć. Šarić ${ }^{1}$, Dragana M. Šoronja-Simović ${ }^{2}$ \\ ${ }^{1}$ University of Novi Sad, Institute of Food Technology, 21000 Novi Sad, Bul. cara Lazara 1, Serbia \\ ${ }^{2}$ University of Novi Sad, Faculty of Technology, 21000 Novi Sad, Bul. cara Lazara 1, Serbia
}

\author{
*Corresponding author: \\ Phone: +381214853778 \\ E-mail: olivera.simurina@fins.uns.ac.rs
}

\begin{abstract}
The aim of this work was to improve the quality of gluten-free bread made with high content of soy flour and enriched with sugar beet molasses by incorporating ingredients with a potential to simultaneously enhance the nutritional quality of the breads. The following ingredients were used: pea protein isolate, pea fibre and chia seeds. The chosen ingredients exerted positive effects on bread quality. They promoted volume increase and crumb softening. In this respect, the most effective ingredients were pea protein isolate (at $1 \%$ supplementation level), pea fibre (at up to $2 \%$ supplementation level) and chia seeds (at $1 \%$ supplementation level). The sensory analysis revealed that pea fibre and chia addition at 1 and $2 \%$ supplementation level provided bread with higher scores regarding overall acceptance, crumb texture and taste. At $1 \%$ supplementation level, there was not found statistically significant difference in sensory attributes of bread supplemented with pea protein isolate in comparison to the control. However, pea protein isolate was found to strongly diminish bread taste at $4 \%$ supplementation level due to presence of beany taste.
\end{abstract}

Key words: pea protein isolate, pea fibre, chia seeds, texture, sensory properties, crumb porosity

\section{INTRODUCTION}

The demand for gluten-free products has been increasing in recent years due to market trends and increasing number of diagnosed celiac and food hypersensitivities such as non-celiac gluten sensitivity and wheat allergy. In spite of large efforts made by researchers and engineers in development and industry, production of high quality gluten-free products still remains a huge technological challenge. Particularly complicated is the gluten-free bread making since gluten is the protein fraction responsible for the formation of a viscoelastic network in dough which plays a key role in the development and final quality of bakery products. To produce gluten-free bread of acceptable quality, it is necessary to form a matrix with sufficient viscoelastic properties for holding $\mathrm{CO}_{2}$ released during fermentation and ability to retain the structure during expansion along baking (Marco and Rosell, 2008).

Most of commercially available gluten-free products are starch based and due to that lack many important nutrients such as proteins, vitamins, minerals, fibres, etc. (Thompson, 2010). Added to that, glutenfree products often have poor functionality having been prone to crumbling texture, high staling tendency, poor colour and mouth feel (Lazaridou et al., 2007; Mariotti et al., 2009). 
Ingredients of choice in gluten-free bread making may include: starches of different origin, flours from non-gluten cereals, pseudocereals and pulses, dairy proteins, other non-gluten proteins, and hydrocolloids. Soybean flour has been used to fortify wheat and gluten-free bread quality and to improve the mechanical behaviour of dough.

Ribotta et al. (2004) studied the feasibility of differently treated soy flours (full-fat enzyme active, semiactive and inactive flours) in production of gluten-free bread. They found that full-fat enzyme active soybean flour was the most beneficial regarding the volume and structure of gluten-free bread. According to their report, this could be attributed to both the structural proteins and the enzymatic activities of soy flour. Soy flour was added in variable amounts over the range $2.5-20 \%$ on rice and cassava flour blend (Ribotta et al., 2004).

Incorporation of protein isolates and fibres in gluten-free bread making is beneficial as it can contribute to enhanced nutritional value (improve protein i.e. fibre content) and better structural properties. Chia seed is a promising ingredient to enhance the nutritional quality of gluten-free bread due to its remarkable composition. It is a rich source of linoleic acid, proteins, antioxidants and fibres. Moreover, chia mucilage gel has been found to act as a soluble fibre with excellent water holding properties which may provide hydration, viscosity development and freshness keeping in baked goods (Felisberto et al. 2015; Steffolani et al., 2014).

This paper presents the results of a study on the development of gluten-free bread formulations based on soybean flour and enriched with molasses.

Soybean flour was used to replace half of the amount of rice flour and $10 \%$ sugar beet molasses (on rice+soy flour basis) was added to enhance the colour and the mineral content of bread (Filipčev, 2011). The main objective of the study was to evaluate the possibilities to further improve the structural and textural properties of breads by incorporating pea protein isolate, pea fibre and chia seeds in its basic formulation.

\section{MATERIALS AND METHODS}

\section{Materials}

Rice flour, dried egg white, margarine, sugar, salt, and dry instant yeast were locally purchased. Soybean flour was provided from „Sojaprotein“, a.d.d., Bečej, Serbia. It was SOPRO-PTB full-fat toasted flour and contained $41 \%$ dry based (d.b.), proteins, $23 \%$ d.b. fat and $7 \%$ moisture. Beet molasses $(82.75 \%$ solids) was supplied by the sugar factory "Crvenka“ a.d. Crvenka, Serbia. Xanthan gum was produced by "Cargill Food and Beverage Ingredients", MN, USA. Pea protein isolate (PISO) was produced by "Producer Fooding group Limited", Shanghai, China and pea fibre (PFIB) were from "International Fiber Corporation", New York, USA. Chia seeds were purchased from a local health food store.

\section{Formulations and preparation of gluten- free bread}

The basic gluten-free formulation contained rice flour $(50 \mathrm{~g})$, soy flour $(50 \mathrm{~g})$, molasses $(10 \mathrm{~g})$, dried egg white powder $(5 \mathrm{~g})$, salt $(2.2 \mathrm{~g})$, margarine $(2 \mathrm{~g})$, dry instant yeast $(2 \mathrm{~g})$, sugar $(1 \mathrm{~g})$, xanthan gum $(0.5 \mathrm{~g})$. To the basic formulation pea protein isolate, pea fibre and chia seeds were added in separate batches at 1,2 and $4 \%$ (rice+soy flour basis). Optimal percentage of water in the formulation was determined in a preliminary testing. Optimal hydration was determined as cohesive and consistent dough without water separation during a 30 min rest, suitable for proofing. In all formulations $155 \%$ water was added except formulations with $4 \%$ pea fibre and pea protein isolate, in which $162 \%$ water was added.

For the breads, all ingredients were mixed in a bowl using a kitchen mixer with wire whip attachment at low speed until the ingredients were combined. Mixing at low speed was continued for a total time of 3 min. The batter was poured into round (muffin) silicone moulds filling no more than $3 / 4$ of the mould ( $60 \mathrm{~g}$ of batter). The divided portions of batter were fermented in a proofing cabinet for $50 \mathrm{~min}$ at $31 \pm 1{ }^{\circ} \mathrm{C}$ and $85 \%$ relative humidity. The batter was then baked at $180{ }^{\circ} \mathrm{C}$ in a MIWE oven during $17 \mathrm{~min}$. Bread was removed from 
the mould after baking and allowed to cool for at least $2 \mathrm{~h}$ on wooden racks before packaging. Cooled breads were wrapped in a plastic foil and further analysed $20 \mathrm{~h}$ after baking. Eight breads were prepared from each formulation.

\section{Bread quality determination}

Specific volume of bread was determined using a laser scan based volumometer (VSP6, VolScan Profiler, Stable Micro Systems, England).

Crumb texture was measured on a texture analyser (TA-XTplus, Stable Micro Systems, England) according to adjusted AACC approved method 74-10A (AACC, 2003). From each bread loaf, one $21 \mathrm{~mm}$ thick slice was cut from the centre of the loaf. Crumb was compressed with a flatend $36 \mathrm{~mm}$ diameter disc (P/36R) to $40 \%$ strain. Firmness was read at $25 \%$ strain as the maximum achieved force at 1.7 $\mathrm{mm} / \mathrm{min}$ rate. Crumb resilience was calculated as the ratio of the area during probe withdrawal to the area of the compression. Disc compression and withdrawal speeds were equal, $1.7 \mathrm{~mm} / \mathrm{min}$. Crumb resilience derived in this way can be described as instant springiness which relates to how well crumb regains its original position after compression. Five replications were measured for each bread type.

\section{Determination of sensory properties}

Sensory properties of gluten-free breads were evaluated by 6 untrained panellists. A 9-point hedonic scale (1-dislike extremely; 9-like extremely) was used to evaluate the overall acceptability, appearance, crumb texture and taste. Crumb porosity was evaluated according to Dallman scale (1-open grain structure; 8-dense grain structure).

\section{Statistical analysis}

In order to assess the effect of studied factors (supplement type and supplementation level), a multiple comparison analysis of samples using Tukey's test (HSD) was undertaken by means of the statistical program Statistica 12 (Tulsa, OK, USA). Confidence level was $95 \%$. All samples were analysed in minimum triplicate if not otherwise mentioned.

\section{RESULTS AND DISCUSSION}

\section{Effect on specific volume}

Effect of pea protein isolate, pea fibre or chia seed addition on the volume of gluten-free breads based on soy and molasses is displayed in Figure 1. The highest volume was obtained at lower level of dosage: $1 \%$ of pea protein isolate $(1.62 \mathrm{ml} / \mathrm{g}), 1$ and $2 \%$ of pea fibre $(1.55$ and $1.58 \mathrm{ml} / \mathrm{g}$ ) and $1 \%$ chia $(1.56 \mathrm{ml} / \mathrm{g})$. The most efficient ingredient was pea protein isolate. Bread volume depends on the balance of gas-forming and gasholding ability of dough (batter in the case of gluten-free systems). In the case of gluten-free breads, structural ingredients such as proteins and fibres play a key role in crumb structure formation and support. Product volume depends on batter viscosity and stability against collapse during baking. Batter properties are related to starch, pentosans and protein properties (Oliete et al. 2010). Structure forming ability of proteins depends on their solubility, swelling ability and emulsification properties (Lazaridou and Biliaderis, 2010). Incorporation of legume flours was reported to increase cake volume (Gularte et al., 2011). Legume proteins are generally recognized to have strong gelforming ability and foam stabilizing ability (Houben et al., 2012). Protein isolates are able to modify the pasting properties of starch. Pea protein was reported to decrease the setback viscosity (Lazaridou and Biliaderis, 2010).

Fibres have the ability to bind water. The water binding capacity depends on their chemical composition and structure, particularly the ratio of water soluble and insoluble fibres. They can exert a multitude of functional properties when incorporated into food systems such as waterholding capacity, gel-forming ability, fat mimetic, antisticking/anticlumping, texturizing and thickening effects (Gelroth and Ranhotra, 2001).

Sabanis et al. (2009) studied the effect of maize fibre on the quality of gluten-free bread and found that maize fibre was able to increase the bread specific volume up to certain limit which was attributed to the 
presence of insoluble fibres and their capability to form a network. A decrease in the specific volume following an increase in fibre dose was associated with the interaction of fibre with starch leading to impaired gas retention capacity and high plasticity of dough as a consequence of extra water which leaded to collapse in structure.

Steffolani et al. (2014) reported that addition of chia seeds in the amount of $15 \%$ (rice flour based) reduced the specific volume of rice flour-based gluten-free bread.

\section{Effect on crumb texture}

The applied ingredients affected the textural properties of gluten-free breads. At the lowest doses used (1\%), all of the ingredients softened the crumb in comparison to the control. However, at higher supplementation levels, crumb firmness tended to increase. The lowest firming tendency was observed in the gluten-free breads supplemented with pea fibre. Generally, in comparison to the control, crumb resilience had a decreasing ten- dency with exception of pea fibre addition. At $1 \%$ addition of pea fibre, crumb resilience increased but at further continued to slightly decrease but it remained higher than that of the control.

The obtained results are in accordance with observations from previous studies (He and Hoseney, 1990) that specific volume is inversely correlated to crumb firmness i.e. breads with higher volume had softer crumb. Fibres usually contribute to higher crumb firmness and denser crumb but their action depends greatly on concentration and the amount of water present. Higher water content promotes softer crumbs. Sabanis et al. (2009) showed that maize fibre was able to induce a decrease of crumb firmness at low levels of addition (up to $5 \%$ flour basis). At higher dose, fibres increased crumb firmness due to higher water absorption capacity. In wheat breads, it was observed that addition of fibres thickens the walls of crumb pores (Gomez et al. 2003). Gan et al. (1989) assumed that fibres act as points of weakness within the expanding dough pore walls.
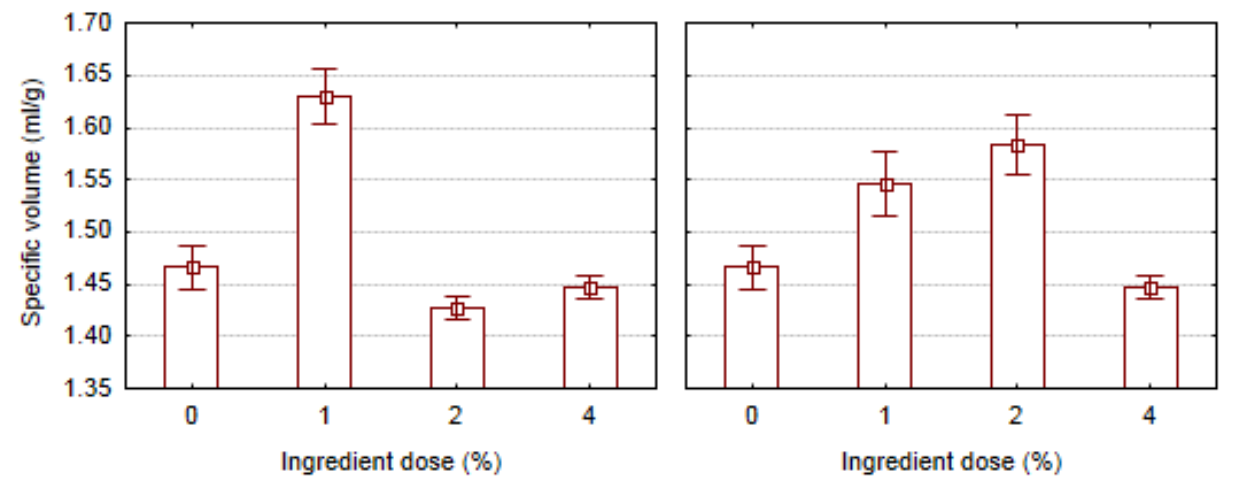

Type of ingredient: PISO

Type of ingredient: PFIB

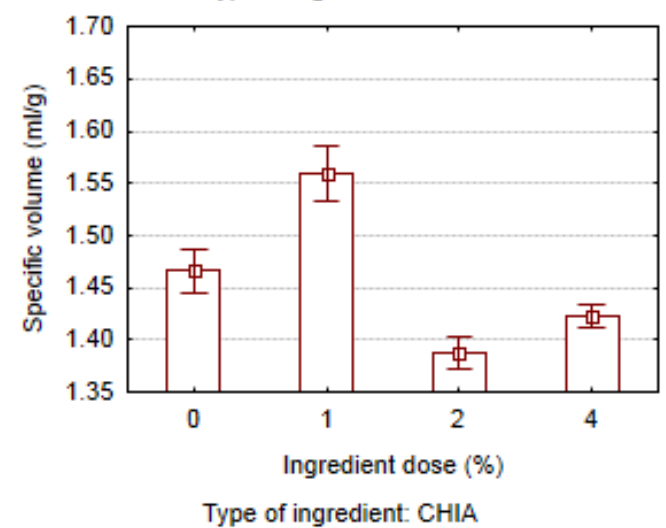

Figure 1. Specific volume of gluten-free breads supplemented with pea protein isolate (PISO), pea fibre (PFIB) and chia seeds (CHIA) 


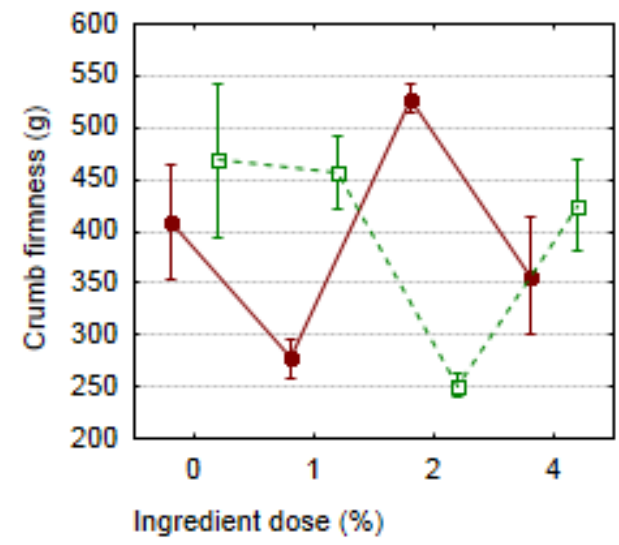

Type of ingredient: PISO

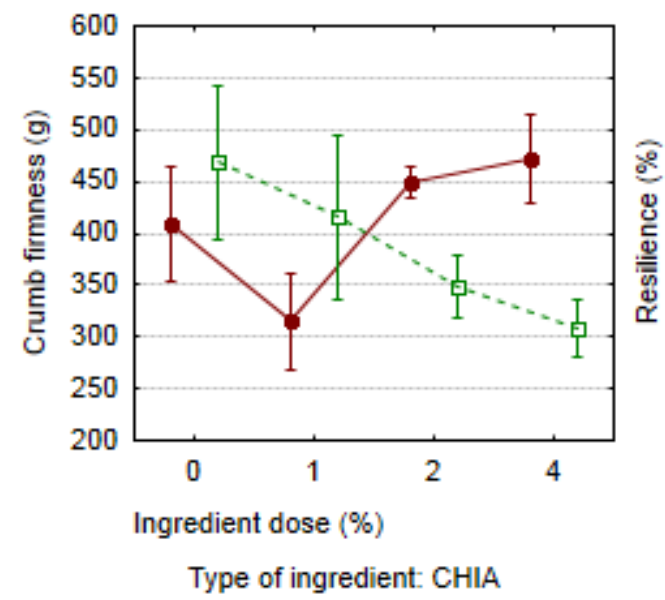

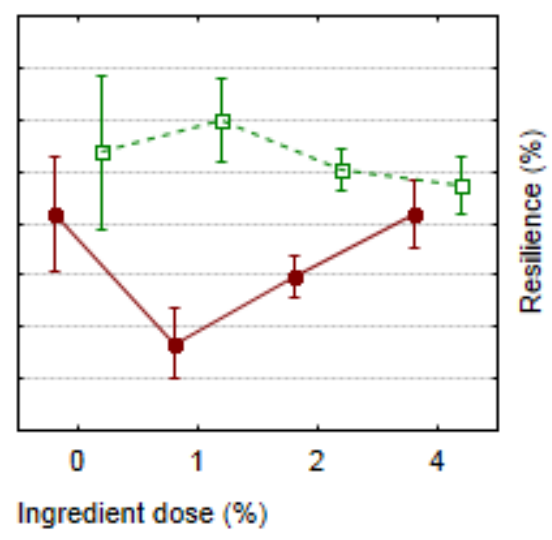

Type of ingredient: PFIB

Figure 2. Effect of pea protein isolate (PISO), pea fibre (PFIB) and chia seed (CHIA) addition on the development of crumb texture in gluten-free breads based on soy and molasses

Protein isolates were also reported to affect crumb firmness. Crockett et al. (2011) found that soy protein isolate at lower addition levels (1-2\%) softened the crumb in gluten-free bread but at higher applied levels increased the firmness due to network formation. They concluded that the ability of soy protein isolate to induce crumb firmness depends on their gelling properties; the higher the gelling of protein isolates, the higher the crumb firmness. Marco and Rosell (2008) reported that when combining pea and soy protein isolate, pea protein isolate tended to increase crumb hardness in rice-based gluten-free bread whereas soy protein decreased it. They also observed that pea and soy protein isolates increased crumb springiness.

Addition of chia seeds at $15 \%$ to rice-based gluten-free breads increased the firmness of bread (Steffolani et al., 2014). This effect was more pronounced in the case when chia flour was used. Moreira et al. (2013) reported that mixing and thermal properties of gluten-free dough based on chestnut flour were improved with the presence of chia flour combined with various hydrocolloids. The improvement was particularly reflected to pasting properties which contributed to the formation of dough with lower apparent viscosity and increased stability and elasticity.

\section{Effect on sensory properties}

Addition of pea protein isolate at 1 and $2 \%$ produced bread with overall acceptability similar to that of the control bread. The highest differences were observed in crumb porosity. At $4 \%$ dose, bread taste was diminished due to perceived beany note.

Gluten-free breads prepared with pea fibre at $2 \%$ dose showed better overall acceptability due to excellent crumb structure and good taste. 

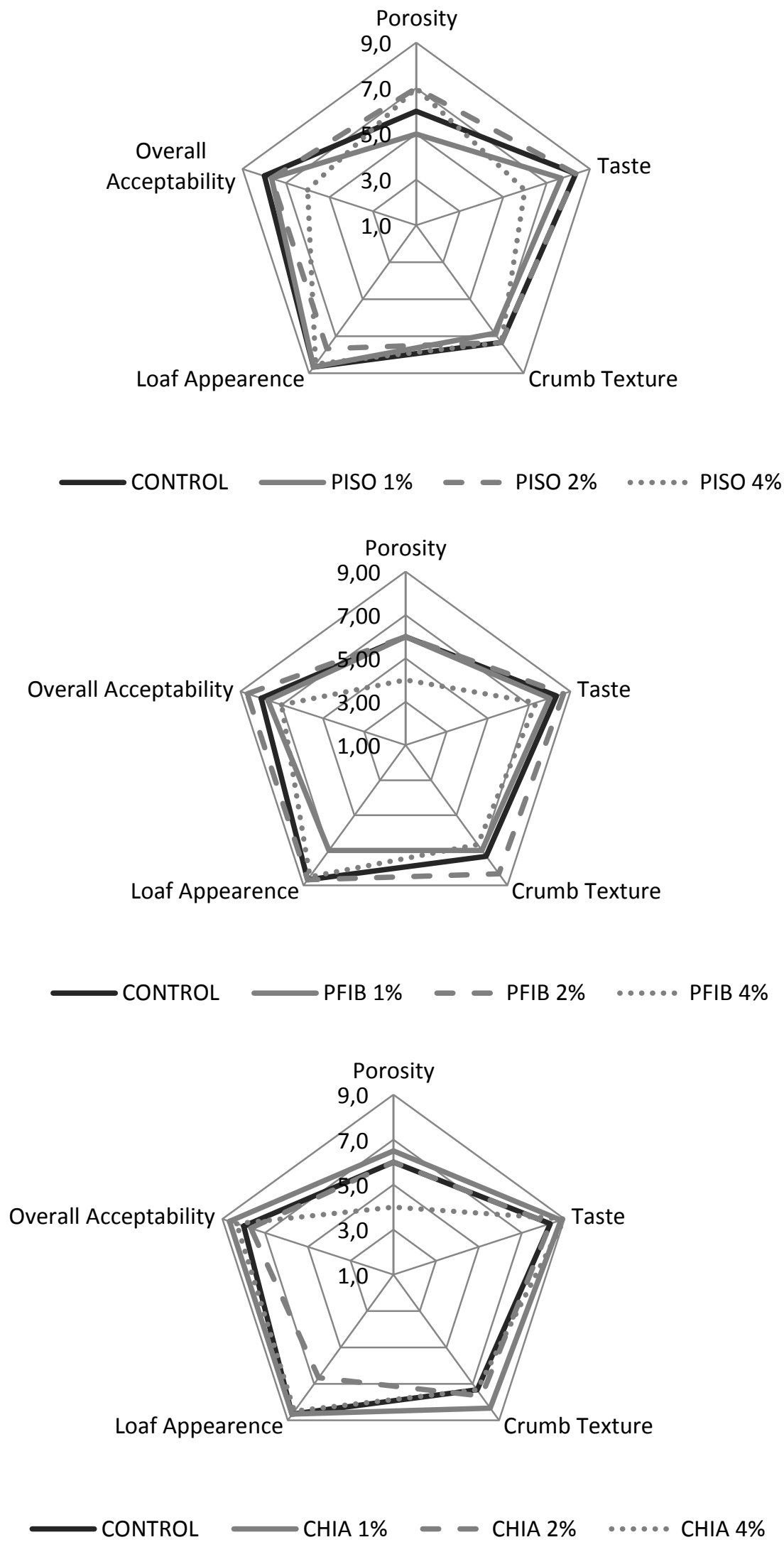

Figure 3. Sensory properties of gluten free bread based on soy as affected by supplementation with 
pea protein isolate (PISO), pea fibre (PFIB) and chia seeds (CHIA)

Chia addition at $1 \%$ level provided breads scored higher for overall acceptability, crumb texture and taste in comparison to the control.

Loaf appearance was mainly impaired at $4 \%$ enrichment level for all studied ingredients.

Generally, results obtained in this preliminary study showed that supplementation at lower doses (1-2\%) with pea protein isolate, pea fibre and chia seeds provided products with the best properties.

\section{CONCLUSIONS}

Individual incorporation of pea protein isolate, pea fibre and chia seed to formulation of gluten-free bread based on soy and enriched with sugar beet molasses resulted in several improvements of bread quality. Significant increase in bread volume and reduction of crumb firmness was obtained at $1-2 \%$ supplementation level with the applied ingredients, among which pea protein isolate and pea fibre were the most efficient. Better sensory scores than for the control were achieved with breads supplemented with chia seed and pea fibre. Therefore, based on the results, it can be suggested that improved quality gluten-free breads with high soybean content were obtained by incorporating $1 \%$ of pea protein isolate or up to $2 \%$ pea fibre or chia seed.

\section{ACKNOWLEDGEMENTS}

This work was supported by funds of the Ministry of Education, Science and Technological Development of the Republic of Serbia (project TR 31055).

\section{REFERENCES}

1. AACC (2003). Approved Methods of the American Association of Cereal Chemists (AACC), $10^{\text {th }}$ Ed. AACC, St. Paul, MN, Method 74-10A.

2. Crockett, R., le, P., Vodovotz, Y. (2011). Effects of soy protein isolate and egg white solids on the physicochemical properties of gluten-free bread. Food Chemistry, 129, 84-91.

3. Felisberto, M.H.F., Wahanik, A.L., Gomez-Ruffi, C.R., Clerici, M.T.P.S., Chang, Y.K. (2015). Use of chia (Salvia hispanica L.) mucilage gel to reduce fat in pound cakes. LWT-Food Science and Technology, 63, 1049-1055.

4. Filipčev, B.V. (2011). Sugar beet molasses: An ingredient to enhance micronutrients and functionality in bread. Food and Feed Research, 38 (2), 95-100.

5. Gan, Z., Ellis, P.R., Vaughan, J.G., Galliard, T. (1989). Some effects of non-endosperm components of wheat and of added gluten on wholemeal bread structure. Journal of Cereal Science, 10, 81-91.

6. Gelroth, J., Ranhotra, G.S. (2001). Food uses of fibre. In Handbook of dietary fibre. Eds. S.S. Cho, M.L. Dreher, Taylor and Francis, New York.

7. Gómez, M., Ronda, F., Blanco, C.A., Caballero, P.A., Apesteguia, A. (2003). Effects of dietary fibre on dough rheology and bread quality. European Food Research and Technology, 216, 51-56.

8. Gularte, M.A., Gómez, M., Rosell, C.M. (2012). Impact of legume flours on quality and in vitro digestibility of starch and protein from glutenfree cakes. Food Bioprocessing and Technology, 5, 3142-3150.

9. He, H., Hoseney, R.C. (1990). Changes in bread firmness and moisture during long-term storage. Cereal Chemistry, 67, 603-608.

10. Houben, A., Höchstötter, A., Becker, T. (2012). Possibilities to increase the quality in glutenfree bread production: an overview. European Food Research Technology, 235, 195-208.

11. Lazaridou, A., Biliaderis, C.G. (2010). Rheological properties, testing procedures-Methods and potential problems. In Gluten-free food: Science and technology. Ed. E. Gallagher, Wiley-Blackwell, A John Wiley \& Sons, Ltd., Publication, Chichester, UK, pp. 52-82.

12. Lazaridou, A., Duta, D., Papageorgiu, M., Belc, N., Biliaderis, C.G. (2007). Effects of hydrocolloids on dough rheology and bread quality parameters in gluten-free formulations. Journal of Food Engineering, 79, 1033-1047.

13. Marco, C., Rosell, C.M. (2008). Functional and rheological properties of protein enriched gluten free composite flours. Journal of Food Engineering, 88, 94-103.

14. Mariotti, M., Lucisano, M., Pagani, M. A., Ng, P. K. W. (2009). The role of corn starch, amaranth flour, pea isolate, and Psyllium flour on the rheological properties and ultrastructure of gluten-free doughs. Food Research International, 42, 963-975.

15. Moreira, R., Chenlo, F., Torres, M.D. (2013). Effect of chia (Sativa hispanica L.) and hydrocolloids on the rheology of gluten-free doughs based on chestnut flour. LWT-Food Science and Technology, 50, 160-166.

16. Oliete, B., Pérez, G.T., Gómez, M., Ribotta, P.D., Moiraghi, M., Léon, A. E. (2010). Use of wheat, triticale and rye flours in layer cake production. International Journal of Food Science and Technology, 45, 697-706. 
17. Ribotta, P.D., Ausar, S. A., Morcillo, M.H., Pérez, G.T., Beltramo, D.M., León, A. (2004). Production of gluten-free bread using soybean flour. Journal of the Science of Food and Agriculture, 84, 1969-1974.

18. Sabanis, D., Lebesi, D., Tzia, C. (2009). Development of fibre-enriched gluten-free bread: a response surface methodology study. International Journal of Food Sciences and Nutrition, 60 (S4), 174-190.
19. Steffolani, E., Hera de la, E., Pérez, G., Gómez, M. (2014). Effect of chia (Salvia hispanica L.) addition on the quality of gluten-free bread. Journal of Food Quality, 37, 309-317.

20. Thompson, T. (2010). The nutritional quality of gluten-free foods. In Gluten-free food: Science and technology. Ed. E. Gallagher, Wiley-Blackwell, A John Wiley \& Sons, Ltd., Publication, Chichester, UK, pp. 42-51.

\section{ПОБОЉШАЊЕ КВАЛИТЕТА БЕЗГЛУТЕНСКОГ ХЛЕБА СА ДОДАТКОМ COJE И МЕЛАСЕ ШЕЋЕРНЕ РEПE}

Оливера Д. Шимурина ${ }^{* 1}$, Александар 3. Радуновић ${ }^{1}$, Бојана В. Филипчев ${ }^{1}$, Рада Ц. Јевтић Мучибабић ${ }^{1}$, Љубиша Ћ. Шарић ${ }^{1}$, Драгана М. Шороња-Симовић ${ }^{2}$

'Универзитет у Новом Саду, Научни институт за прехрамбене технологије у Новом Саду, 21000 Нови Сад, Булевар цара Лазара 1, Србија

${ }^{2}$ Универзитет у Новом Саду, Технолошки фракултет, 21000 Нови Сад, Булевар цара Лазара 1, Србија

Сажетак: Циљ рада био је да се побољша квалитет безглутенског хлеба са високим садржајем сојиног брашна обогаћеног меласом шећерне репе додатком сировина које истовремено могу да допринесу побољшању нутритивног састава хлеба. Одабрани су следећи састојци: изолат протеина грашка, влакна грашка и чија семе. Одабрани састојци су побољшали квалитетна својства безглутенског хлеба на тај начин што су повећали запремину и мекоћу средине. У овом смислу, најефикаснијим су се показали изолат грашка (при концентрацији $1 \%$ рачунато на безглутенско брашно), влакна грашка (до $2 \%)$ и чија семе (1\%). Сензорска анализа је показала да хлеб са додатком влакана грашка и чија семена даје хлеб бољих сензорских својстава захваљујући бољем спољном изгледу, текстурним својствима средине и укусу. При концентрацији 1\%, додатак изолата протеина грашка није довео до значајне промене сензорских својстава хлеба у односу на контролни узорак. Међутим, при вишим нивоима суплементације (4\%), изолат протеина грашка је негативно утицао на укус хлеба због појаве укуса на махунарке.

Кључне речи: изолат протеина грашка, влакна грашка, чија семе, текстура, сензорска својства, порозност средине

Received: 17 April 2017

Accepted: 7 June 2017 